\title{
Correction to: Galanin Peptides Alleviate Myocardial Ischemia/ Reperfusion Injury by Reducing Reactive Oxygen Species Formation
}

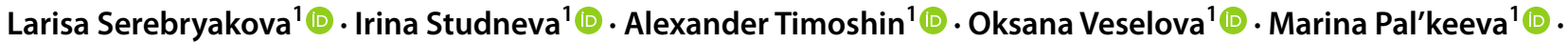

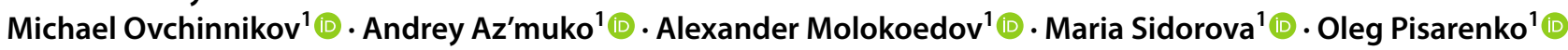

Published online: 1 June 2021

○) Springer Nature B.V. 2021

\section{Correction to: \\ International Journal of Peptide Research and Therapeutics https://doi.org/10.1007/s10989-021-10231-x}

The original version of this article unfortunately contained incorrect page numbers and DOI in reference Pisarenko et al. (2021).

The correct reference should read as:

Pisarenko O, Studneva I, Serebryakova L et al. (2021) Antioxidant properties of galanin and its $\mathrm{N}$-terminal fragments in in vitro and in vivo oxidative stress modeling. Biochemistry (Moscow) 86(4):496-505. https://doi.org/10. 1134/S0006297921040106

The original article can be found online at https://doi.org/10.1007/ s10989-021-10231-x

Oleg Pisarenko

olpi@live.ru

Larisa Serebryakova serebrolar09@yandex.ru

Irina Studneva imstudneva@gmail.com

Alexander Timoshin timoshin_a_a@mail.ru

Oksana Veselova venatormma@mail.ru

Marina Pal'keeva mpalkeeva@mail.ru
Also, its corresponding in-text citation should be Pisarenko et al. (2021) instead of Pisarenko (2021).

The original article has been corrected.

Publisher's Note Springer Nature remains neutral with regard to jurisdictional claims in published maps and institutional affiliations.
Michael Ovchinnikov peptide-mv@mail.ru

Andrey Az'muko aazmuko@yandex.ru

Alexander Molokoedov asmolokoedov@yandex.ru

Maria Sidorova mvs.peptide@gmail.com

1 National Medical Research Center for Cardiology, 3rd Cherepkovskaya Str., 15A, Moscow, Russian Federation 121552 